DOI : https://doi.org/10.24843/JFU.2020.v09.i03.p09

pISSN: 2301-7716; eISSN: 2622-4607

Jurnal Farmasi Udayana, Spesial Issue Desember 2020, 204-212

\title{
Potensi Nefroterapi Daun Nangka (Artocarpus heterophyllus Lamk) Terhadap Tikus Putih Diabetes Melitus
}

\author{
Tandi, J. ${ }^{1}$, Nugraha, F.R. ${ }^{1}$, Afandi, W.N. \\ ${ }^{1}$ Program Studi S1 Farmasi, STIFA Pelita Mas Palu, Jl. Monginsidi No.106 A, Palu, Indonesia, 94125 \\ e-mail: jonitandi757@yahoo.com
}

Riwayat artikel: Dikirim: 15/10/2020; Diterima: 27/10/2020, Diterbitkan: 15/12/2020

\begin{abstract}
The Kalili tribe in Palu uses jackfruit leaves as a lumbago in the form of dry simplicia. In addition, jackfruit leaves are used to destroy oxalate stones in the kidneys. Based on this experience, we conducted a study that aimed to determine the content of secondary metabolite compounds of ethanol extract of jackfruit leaves, to determine the effect of ethanol extract of jackfruit leaves on the histopathological picture of streptozotocin induced rats in rats, and to determine the dose of ethanol extract of jackfruit leaves which was effective in regenerating cells in kidney tubules. This study used 25 male white rats divided into 5 groups, namely group I as normal control, group II as negative control given $0.5 \% \mathrm{Na}-\mathrm{CMC}$ suspension, groups III, IV and VI as the test group given ethanol extract of jackfruit leaves with each dose $175 \mathrm{mg} / \mathrm{kg} \mathrm{BW}, 250 \mathrm{mg} / \mathrm{kg} \mathrm{BW}, 400 \mathrm{mg} /$ $\mathrm{kg} \mathrm{BW}$. Data were analyzed using the one way ANOVA test at the $95 \%$ level of confidence, and continued with the LSD post hoc test. The results of this study indicate that the ethanol extract of jackfruit leaves contains secondary metabolites, namely flavonoids, alkaloids, saponins, tannins and polyphenols and can reduce blood glucose levels of $100.8 \pm 36.8 \mathrm{mg} / \mathrm{dL}$ and regenerate kidney tubular cells with an average score of 0.6 with a maximum damage value of 4 .
\end{abstract}

Keywords: Jackfruit leaves (Artocarpus heterophylus Lamk), Diabetes, Kidney Histopathology.

\begin{abstract}
ABSTRAK
Masyarakat suku kalili di Palu menggunakan daun nangka sebagai salah satu obat sakit pinggang dalam bentuk simplisia yang kering. Selain itu daun nangka digunakan sebagai penghancur batu oksalat di ginjal. Berdasarkan pengalaman ini kami melakukan penelitian yang bertujuan untuk mengetahui kandungan senyawa metabolit sekunder ekstrak etanol daun nangka, mengetahui efek ekstrak etanol daun nangka terhadap gambaran histopatologi ginjal tikus yang diinduksi streptozotocin, serta mengetahui dosis ekstrak etanol daun nangka yang efektif meregenerasi sel pada tubulus ginjal. Penelitian ini menggunakan 25 ekor tikus putih jantan dibagi menjadi 5 kelompok yaitu kelompok I sebagai kontrol normal, kelompok II sebagai kontrol negatif yang diberikan suspensi Na-CMC 0,5\%, kelompok III, IV dan VI sebagai kelompok uji diberikan ekstrak etanol daun nangka dengan masing-masing dosis $175 \mathrm{mg} / \mathrm{kg} \mathrm{BB}, 250 \mathrm{mg} / \mathrm{kg} \mathrm{BB}, 400 \mathrm{mg} / \mathrm{kgBB}$. Data dianalisis mengunakan uji one way ANOVA pada taraf kepercayaan $95 \%$, dan dilanjutkan dengan uji post hoc LSD. Hasil penelitian ini menunjukkan bahwa ekstrak etanol daun nangka mengandung senyawa metabolit sekunder yaitu flavonoid, alkaloid, saponin, tanin dan polifenol dan dapat menurunkan kadar glukosa darah $100,8 \pm 36,8 \mathrm{mg} / \mathrm{dL}$ dan meregenerasi sel tubulus ginjal dengan skoring rata-rata 0,6 dengan nilai kerusakan maksimal 4
\end{abstract}

Kata kunci : Daun nangka (Artocarpus heterophylus Lamk), Diabetes, Histopatologi Ginjal 
DOI : https://doi.org/10.24843/JFU.2020.v09.i03.p09

pISSN: 2301-7716; eISSN: 2622-4607

Jurnal Farmasi Udayana, Spesial Issue Desember 2020, 204-212

\section{PENDAHULUAN}

Diabetes Melitus merupakan penyakit kelainan metabolik yang ditandai dengan meningkatnya kadar glukosa dalam darah akibat kekurangan atau penurunan efektifitas insulin. Insulin merupakan hormon peptida yang disekresikan oleh sel $\beta$ pankreas. Hormon ini berfungsi dalam mengatur kadar normal glukosa darah. Kelainan sekresi atau kerja insulin menyebabkan gangguan dalam metabolisme karbohidrat, lemak dan protein. Resistensi insulin sering dikaitkan dengan terganggunya sensitivitas jaringan terhadap insulin, hal ini dikarenakan insulin tidak mampu untuk merangsang penyerapan glukosa dalam jaringan target insulin, seperti otot dan lemak (Prabawati, R.K. 2012).

Ginjal adalah organ yang memiliki fungsi penting dalam tubuh, menyediakanmekanisme ekskretoris sebagai bagian dari saluran kemih, saluran untuk menghilangkan limbah metabolism dan sebagainya. Gangguan fungsi ginjal dapat disebabkan oleh beberapa faktor, diantaranya dapat disebabkan oleh penyakit hipertensi, adanya sumbatan pada saluran kemih, infeksi saluran kemih, autoimun dan diabetes melitus (Cahyaningsih, R.A, dkk, 2011).

Pengunaan obat alami mulai berkembang karena efek samping yang hampir tidak ada jika digunakan secara benar, tanaman yang memiliki sebagai efek antidiabetes adalah salah satunya daun nangka, daun nangka banyak terdapat di masyarakat. Selain buahnya dapat dimakan, diharapkan bagian lain dari tumbuhan ini juga dapat dimanfaatkan. Hasil skrining fitokimia daun nangka, mengandung beberapa senyawa yaitu, flavonoid, alkaloid, saponin, glikodida, steroid dan tannin (Baha, K.M 2015).

Penelitian terdahulu ekstrak daun nangka terhadap kadar glukosa darah tikus yang diinduksi aloksan. dengan diinjeksi aloksan 150 $\mathrm{mg} / \mathrm{kgBB}$ secara intraperitoneal. Diberi ekstrak etanol daun nangka dosis $0,125 \mathrm{~g} / \mathrm{kgBB}, 0,250$ $\mathrm{g} / \mathrm{kgBB}$ dan $0,500 \mathrm{~g} / \mathrm{kgBB}$. Kadar glukosa darah dibaca dengan spektrofotometer visibel pada analisis data memakai uji Wilcoxon dengan taraf kepercayaan 95\%. Ekstrak etanol daun nangka mampu menurunkan kadar glukosa darah pada tikus yang diinduksi aloksan $(\mathrm{p}<0,05)$ (Baha, K.M 2015). Penelitian lain yang dilakukan dengan metode infusa menyebutkan bahwa nangka memiliki aktivitas antibakteri yang tinggi dengan nila presentase mencapai 70\% (Yusriana. 2014). Penelitian lain menyebutkan bahwa dari hasil isolasi ekstrak n-butanol nangka diperoleh senyawa isoquercitrin yang menunjukan aktivitas farmakologinya sebagai antidiabetes (Omar. 2011).

Berdasarkan uraian di atas maka peneliti tertarik untuk melakukan penelitian lebih lanjut, untuk mengetahui uji efek ekstrak etanol daun nangka masing-masing dosis $175 \mathrm{mg} / \mathrm{kgBB}$, $250 \mathrm{mg} / \mathrm{kgBB}$ dan $400 \mathrm{mg} / \mathrm{kg}$ BB dalam memberikan hasil yang maksimal untuk menurunkan kadar glukosa darah dan regenerasi jaringan ginjal tikus putih jantan yang diinduksi streptozotocin. Penelitian ini diharapkan dapat menjadi sumber informasi baru untuk masyarakat tentang khasiat daun nangka.

\section{BAHAN DAN METODE}

\subsection{Alat}

Ayakan nomor 40 mesh, bejana maserasi, Blender (Cosmos), Glukotest strip test (Accu chek), kandang hewan uji, penangas air, Rotary vaccum evaporator (Eyela), sonde oral $3 \mathrm{ml}$ (Terumo Syringe), spuit injeksi $1 \mathrm{ml}, 3 \mathrm{ml}$ (Terumo Syringe), Spuit oral $3 \mathrm{ml}, 5 \mathrm{ml}$ (Terumo Syrinege), spot plate, timbangan analitik (Ohaus), dan alat-alat gelas Tabung reaksi (Pyrex),

\subsection{Bahan}

Air suling, Aluminium foil, Aqua pro injeksi (Otsuka), Asam klorida pekat P (Merck), Asam sulfat (Merck), Asam asetat anhidrat (Merck), Asam sitrat, Besi (III) klorida (Merck), Ekstrak etanol daun nangka 96\% (Merck), Eter, Handskun, Hewan Uji, Kertas saring, Liebermann-Burchard (Merck), Natrium klorida, Natrium sitrat, Natrium Carboxymethyle 
DOI : https://doi.org/10.24843/JFU.2020.v09.i03.p09

pISSN: 2301-7716; eISSN: 2622-4607

Jurnal Farmasi Udayana, Spesial Issue Desember 2020, 204-212

Cellulose (Bioworld), Serbuk magnesium P, Streptozotocin (Bioworld USA).

\subsection{Ekstrak Etanol Daun Nangka}

Pembuatan ekstrak daun nangka dilakukan dengan metode maserasi, yaitu serbuk daun nangka yang telah diayak menggunakan ayakan no. 40 mesh, ditimbang 600 gram lalu diekstraksi dengan menggunakan pelarut etanol $96 \%$ sebanyak 3 liter selama 3 hari. Ekstrak kemudian disaring menggunakan kertas saring lalu diperoleh filtrat. Selanjutnya dievaporasi atau memisahkan larutan menggunakan Rotary Vaccum Evaporator pada suhu $60^{\circ} \mathrm{C}$ dan dilanjutkan dengan pengentalan yang dilakukan dengan menggunakan waterbath dengan suhu $60^{\circ} \mathrm{C}$ hingga diperoleh ekstrak kental.

\subsection{Pembuatan Larutan Koloidal Na CMC $0,5 \%$}

Natrium karboksimetil selulosa $(\mathrm{Na}$ CMC) ditimbang sebanyak 0,5 gram ditaburkan dalam lumpang yang berisi $10 \mathrm{ml}$ aquades yang telah dipanaskan, didiamkan selama 15 menit hingga diperoleh massa yang transparan, lalu dicampurkan sampai homogen. Larutan $\mathrm{Na}$ CMC dipindahkan ke dalam labu ukur $100 \mathrm{ml}$. Volumenya dicukupkan dengan aquades hingga $100 \mathrm{ml}$.

\subsection{Pembuatan Suspensi Glibenklamid}

Dosis Glibenklamid pada manusia dewasa adalah $5 \mathrm{mg}$ per hari, jika dikonversi pada tikus dengan berat $200 \mathrm{~g}$ adalah 0,018 maka dosis Glibenklamid untuk tikus adalah $0,45 \mathrm{mg} / \mathrm{kg} \quad$ BB. Ditimbang serbuk glibenklamid yang setara dengan $3,6 \mathrm{mg}$ kemudian disuspensi dalam $\mathrm{Na}$ CMC 0,5\% hingga $100 \mathrm{ml}$. kocok hingga homogen.

\subsection{PembuatanLarutan Streptozotocin (STZ)}

Streptozotocin ditimbang sebanyak 0,24 gram lalu dilarutkan menggunakan citrate-buffer saline dengan $\mathrm{pH}$ 4,5 lalu diinduksikan pada tikus melalui intraperitoneal (ip). Dosis streptozotocin yaitu $30 \mathrm{mg} / \mathrm{kg}$ BB.

\subsection{Analisis Data}

Data yang diperoleh berupa kadar glukosa darah dianalisis secara statistik menggunakan uji one way ANOVA pada tingkat kepercayaan 95\%. Selanjutnya dilakukan uji lanjut Post Hoc Least Significant Difference (LSD). Untuk mengetahui sedian yang efektif memberikan hasil yang maksimal. Data scoring kerusakan ginjal, dianalisis secara statistika menggunakan uji Kruskal-Wallis dilanjutkan dengan uji MannWhitney untuk mengetahui perbedaan antar semua kelompok perlakuan. Pengolahan data menggunakan program SPSS. 
DOI : https://doi.org/10.24843/JFU.2020.v09.i03.p09

pISSN: 2301-7716; eISSN: 2622-4607

Jurnal Farmasi Udayana, Spesial Issue Desember 2020, 204-212

\section{HASIL}

Bahan yang uji yang digunakan adalah daun nangka yang diperoleh dari kota Palu, Sulawesi Tengah. Determinasi dilakukan di UPT Sumber Daya Hayati Sulawesi Tengah, Universitas Tadulako. Hasil determinasi tanaman menunjukan bahwa yang digunakan adalah benar Artocarpus heterophyllus Lamk, yang termasuk familia Moraceae.

Tabel 1. Hasil uji kuantitatif ekstrak etanol daun nangka
Hasil uji kuantitatif kandungan fitokimia ekstrak daun nangka dapat dilihat pada Tabel 1. Ekstrak daun Nangka mengandung flavonoid, alkaloid, tannin, saponin dan fenol.

\begin{tabular}{llcc}
\hline $\mathbf{N o}$ & Parameter Uji & Hasil & Satuan \\
\hline $\mathbf{1}$ & Total flavonoid ekuivalen kuersetin & 8,76 & $\% / \mathrm{bb}$ \\
\hline $\mathbf{2}$ & Total alkaloid ekuivalen kuinin & 3,03 & $\% / \mathrm{bb}$ \\
\hline $\mathbf{3}$ & Total tanin ekivalen asam & 44,54 & $\% / \mathrm{bb}$ \\
\hline $\mathbf{4}$ & Saponin & 32,66 & $\% / \mathrm{bb}$ \\
\hline $\mathbf{5}$ & Total fenol ekivalen asam galat & 3,17 & $\% / \mathrm{bb}$ \\
\hline
\end{tabular}

Sumber : Data premier 2020

Kadar glukosa darah tikus pada beberapa kelompok perlakuan pada hari ke-0 sampai hari ke-28 dapat dilihat pada Tabel 2.

Tabel 2. Rerata hasil pengukuran kadar glukosa darah tikus setelah pemberian esktrak etanol daun nangka

\begin{tabular}{cccccccc}
\hline & \multicolumn{7}{c}{ Rerata \pm SD kadar glukosa darah (mg/dL) } \\
\cline { 2 - 8 } $\begin{array}{c}\text { Hari } \\
\text { ke }\end{array}$ & $\begin{array}{c}\text { kontrol } \\
\text { normal }\end{array}$ & $\begin{array}{c}\text { Kontrol } \\
\text { negatif } \\
\text { kontrol positif } \\
\text { (glibenklamid) }\end{array}$ & $\begin{array}{c}\text { dosis } 175 \\
\text { mg/kg BB }\end{array}$ & $\begin{array}{c}\text { dosis } 250 \\
\mathrm{mg} / \mathrm{kg} \mathrm{BB}\end{array}$ & $\begin{array}{c}\text { dosis } 400 \\
\mathrm{mg} / \mathrm{kg} \mathrm{BB}\end{array}$ & $\mathrm{P}$ \\
\hline 0 & $72,4 \pm 5,6$ & $83 \pm 20,4$ & $76,2 \pm 3,1$ & $77,6 \pm 5,12$ & $76,4 \pm 6,3$ & $64,2 \pm 3,4$ & 0,109 \\
\hline 7 & $73,8 \pm 2,6$ & $413,4 \pm 126,3$ & $361,6 \pm 81,5$ & $486 \pm 86,3$ & $327,8 \pm 106,4$ & $395 \pm 89,1$ & 0,000 \\
\hline 14 & $112,2 \pm 5,8$ & $535,6 \pm 28,5$ & $272,8 \pm 124,8$ & $397,2 \pm 125,8$ & $284 \pm 115,6$ & $345,4 \pm 93,3$ & 0,000 \\
\hline 21 & $118,4 \pm 9,7$ & $399,8 \pm 119,3$ & $172 \pm 94,3$ & $259,2 \pm 166,6$ & $123,2 \pm 24,6$ & $128,2 \pm 25,3$ & 0,001 \\
\hline 28 & $104,4 \pm 6,9$ & $453,4 \pm 125,4$ & $92,8 \pm 23,8$ & $100,8 \pm 36,8$ & $109,6 \pm 17,1$ & $105,8 \pm 15,4$ & 0,000 \\
\hline
\end{tabular}


DOI : https://doi.org/10.24843/JFU.2020.v09.i03.p09

pISSN: 2301-7716; eISSN: 2622-4607

Jurnal Farmasi Udayana, Spesial Issue Desember 2020, 204-212

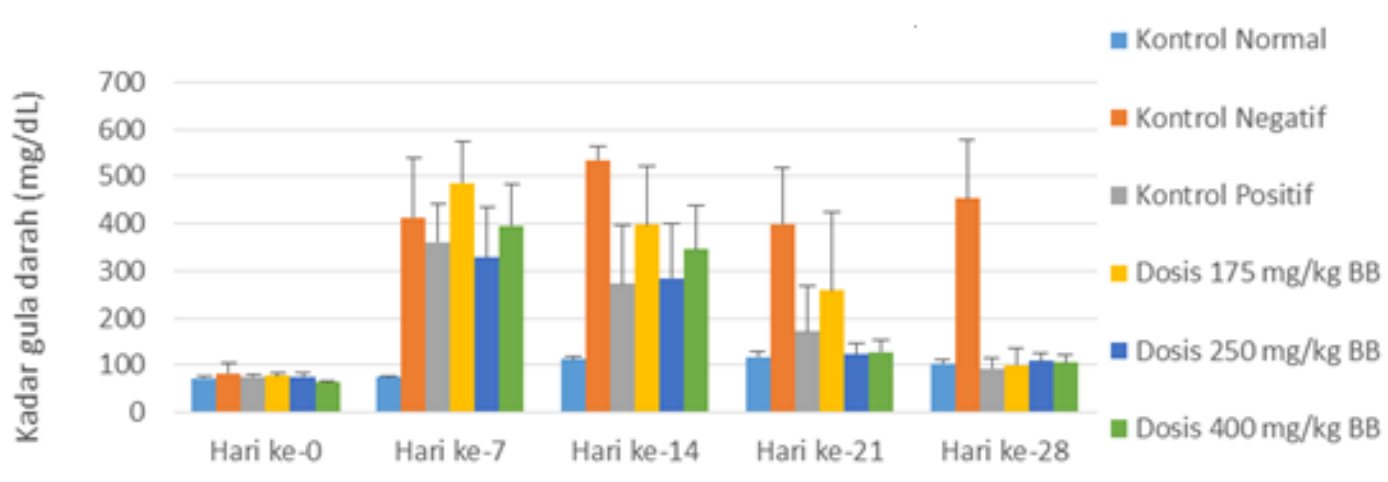

Gambar 1. Grafik kadar glukosa darah tikus putih jantan setiap kelompok pada hari ke 0, ke 7, ke 14, ke 21 dan ke 28

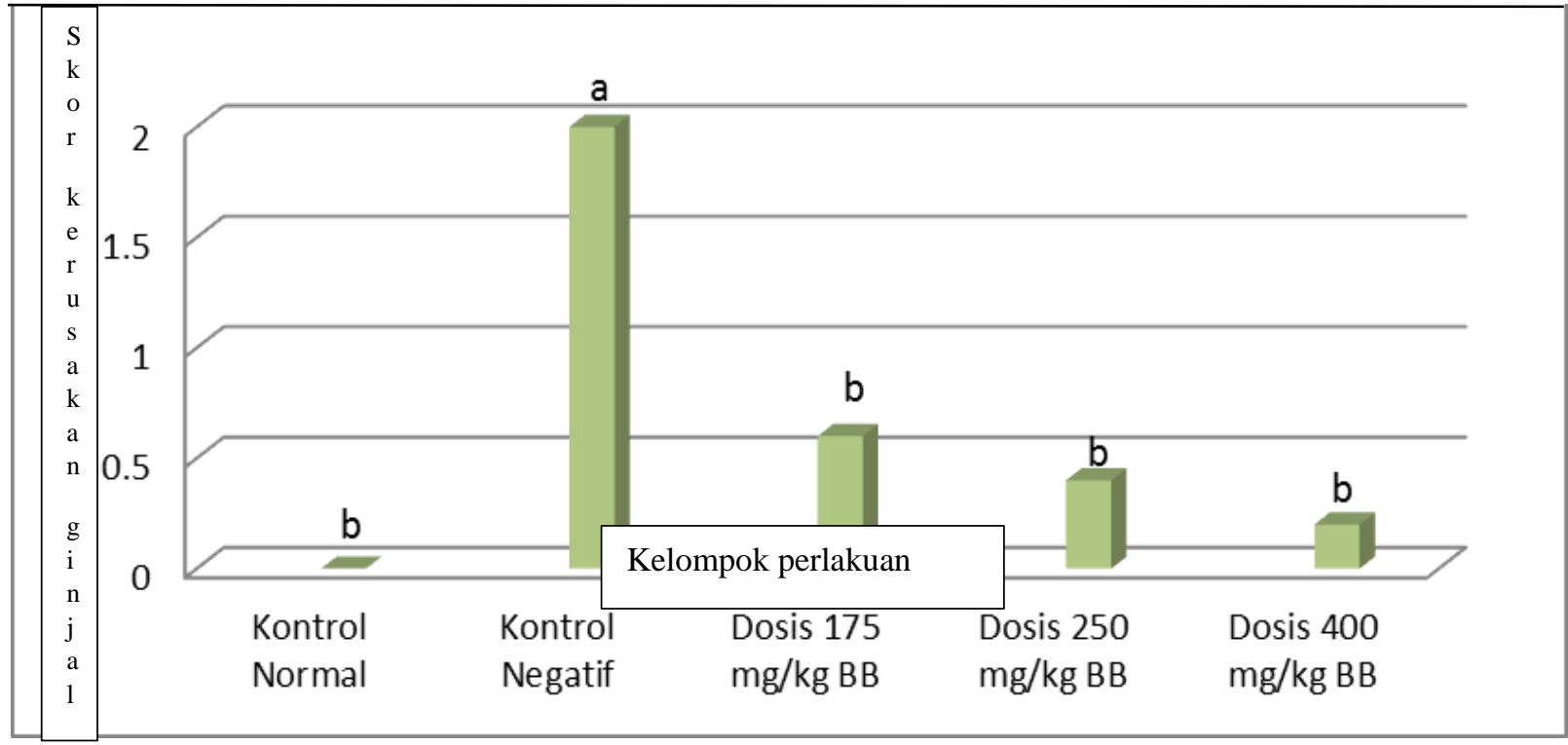

Gambar 2. Diagram batang tingkat kerusakan histopatologi ginjal tikus

Pengaruh pemberian ekstrak etanol daun nangka terhadap kadar glukosa darah pada tikus putih jantan setiap kelompok pada hari ke 0 , ke 7, ke 14, ke 21 dan ke 28 dapat dilihat pada Gambar 1. Kerusakan ginjal hewan coba akibat pemberian ektrak daun nangka pada berbagai dosis pemberian dapat dilihat pada Gambar 2. 
DOI : https://doi.org/10.24843/JFU.2020.v09.i03.p09

pISSN: 2301-7716; eISSN: 2622-4607

Jurnal Farmasi Udayana, Spesial Issue Desember 2020, 204-212
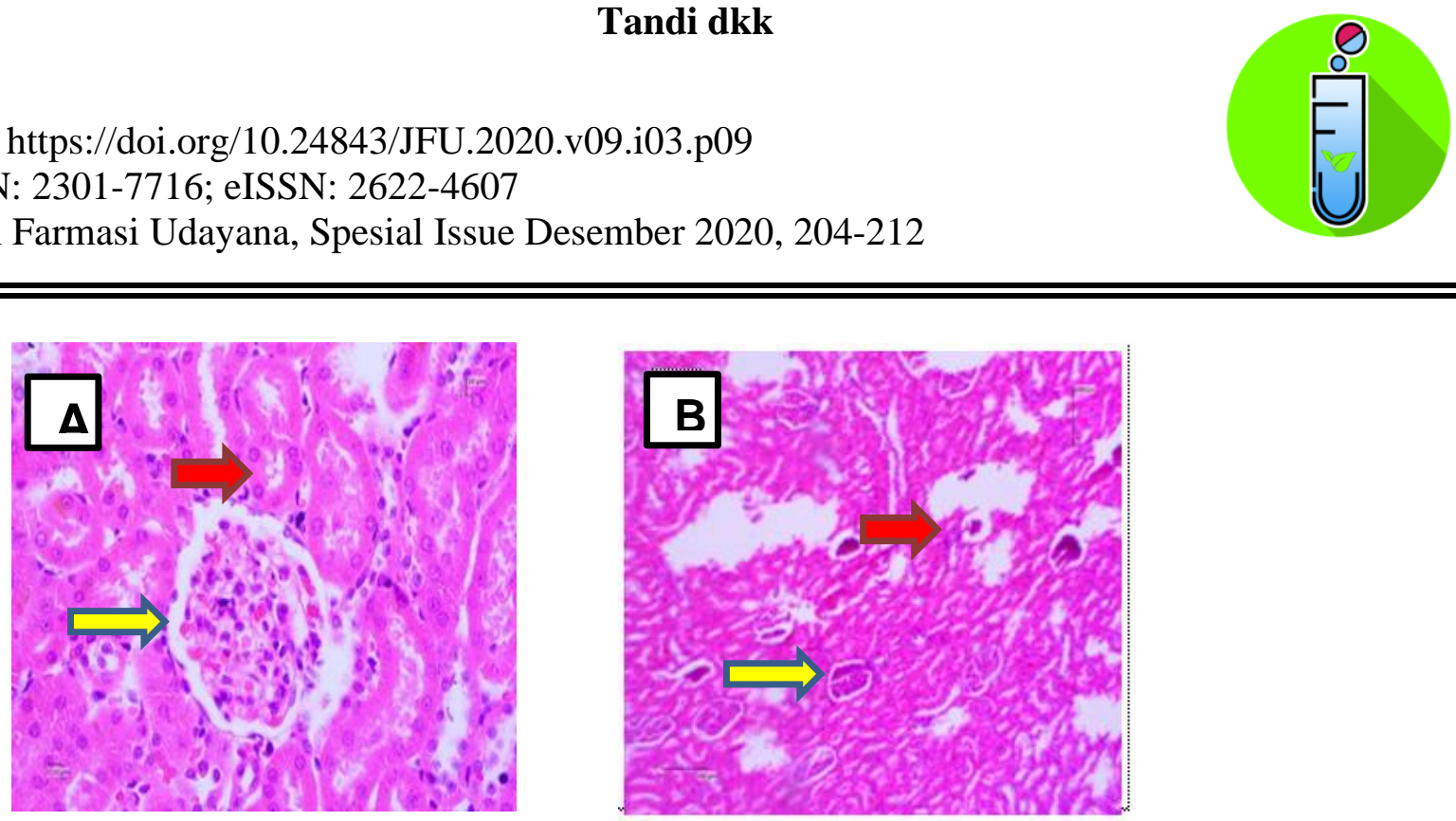

Gambar 3 Gambaran histopatologi sel glomerulus dan tubulus ginjal tikus putih jantan perbesaran 400x dengan pewarnaan H\&E (Skor 0). Ketengaran : $\quad \longrightarrow \quad$ Sel Glomerulus Normal, $\longmapsto$ Sel Tubulus Normal
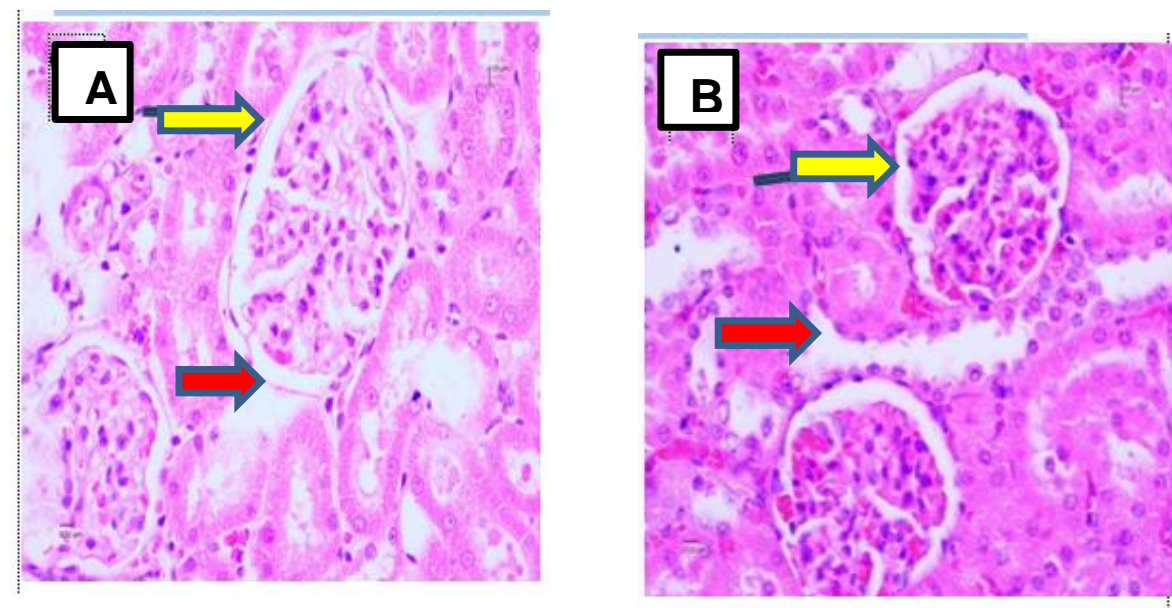

Gambar 4 Gambaran histopatologi sel glomerulus dan sel tubulus ginjal tikus putih jantan perbesaran 400x dengan pewarnaan H\&E (Skor 1). Keterangan : Glomerulus : Kerusakan ringan $\longrightarrow$ Sel Tubulus : Mengalami degeneratif

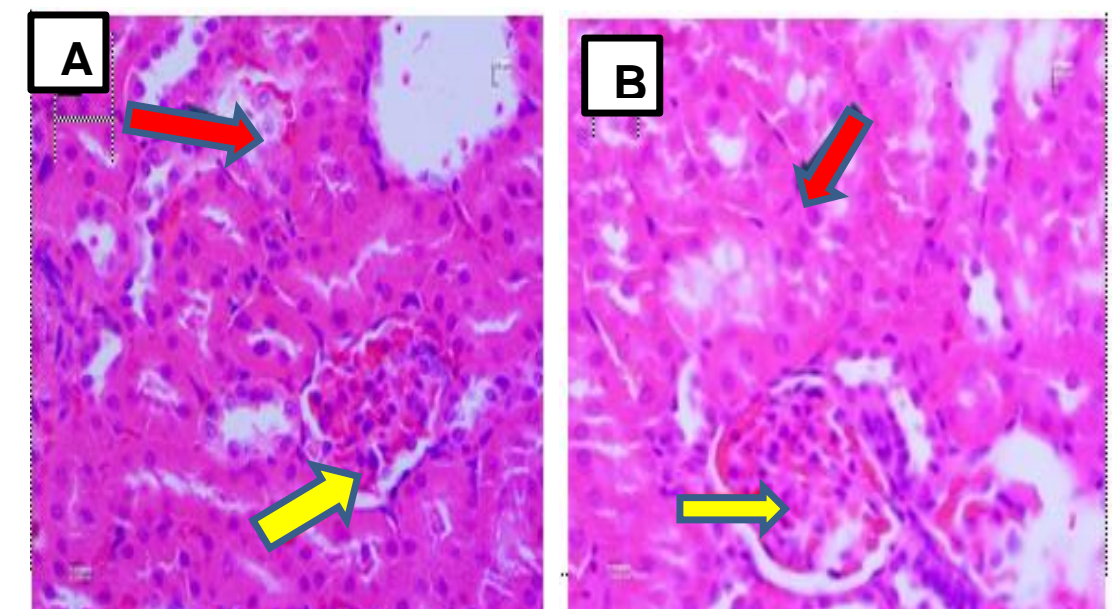

Gambar 5 Gambaran histopatologi sel tubulus ginjal tikus putih jantan perbesaran 400x dengan pewarnaan H\&E (Skor 2). Keterangan $\square$ Sel Glomerulus: Terjadi apoptosis, $\square$ Sel Tubulus : Terjadi kerusakan 
DOI : https://doi.org/10.24843/JFU.2020.v09.i03.p09

pISSN: 2301-7716; eISSN: 2622-4607

Jurnal Farmasi Udayana, Spesial Issue Desember 2020, 204-212

Pada Gambar 3.A sel glomerulus dan sel tubulus menunjukkan normal dan segar. Hal ini disebabkan dengan lengkungan henle Nampak jelas tidak ada menunjukkan kerusakan dan pada sel glomerulus dan sel tubulus semua nampak terlihat normal. Pada Gambar 3.B sel glomerulus dan sel tubulus dan nampak terlihat tidak ada terjadi perubahan, bentuk oval dan menunjukkan tidak terjadi inflamasi

Pada gambar 4.A Preparat jaringan histopatologi ginjal tikus putih skor 1 (terjadi perubahan struktur yang melibatkan $<25 \%$ lapang pandang) Pada gambar 4.A tampak terjadi glomerulus inflamasi ukuran sudah terjadi perubahan yang lebih besar dan lingkungan henle dan pada sel tubulus telah menunjukkan sel dalam keadaan mengalami degeneratif. Pada gambar 4.B ukuran sel glomerulus tanpak terjadi perubahan ukuran yang lebih kecil dan terjadi pelengketan dan degeneratif pada sel tubulus terjadi inflamasi.

Pada gambar 5.A Preparat jaringan histopatologi ginjal tikus putih skor 2 (terjadi perubahan struktur yang melibatkan 25\%-50\% lapang pandang) pada gambar 5.A sel glomerulus terjadi apotosis disertai dengan adanya perubahan ukuran dan bentuk yang telah menunjukkan kematian sel dan pada tubulus terjadi perubahan yang ditandai dengan inflamasi inti sel dan terjadi kerusakkan. Pada gambar 5.B sel glomerulus telah mengalami kematian sel dimana ditandai dengan sel yang mengalami apotosis dan pada sel tubulus mengalami inflamasi.

\section{PEMBAHASAN}

Penelitian ini digunakan untuk melihat pengaruh pemberian ekstrak etanol daun nangka terhadap kadar glukosa darah, dan pada gambar histopatologi ginjal tikus putih jantan dengan mengukur kadar glukosa,hari ke-14, 21 dan ke-28 dan pada hari ke 28 tikus di korbankan dan diambil organ ginjalnya untuk dilakukan pemeriksaan organ ginjal tikus putih jantan.

Penelitian ini menggunakan hewan uji berupa tikus putih jantan (Rattus norvegicus) sebanyak 30 ekor. Penggunaan tikus putih jantan sebagai hewan uji karena dapat memberikan hasil penelitian yang lebih stabil karena tidak dipengaruhi oleh siklus estrus dan kehamilan seperti pada tikus putih betina.Tikus putih jantan juga mempunyai kecepatan metabolisme obat yang lebih cepat dan kondisi biologis tubuh yang lebih stabil dibanding tikus betina (Tandi, J. 2017).

Tikus putih jantan diabetes diberi perlakuan selama 14 hari yaitu pada kelompok 1 merupakan kontrol normal, kelompok 2 tikus diberi larutan koloidal $\mathrm{Na} \mathrm{CMC} 0,5 \%$ sebagai kontrol negatif, kelompok 3, 4 dan 5 tikus diberi ektstrak etanol daun nangka kemudian dilakukan pengukuran kadar glukosa darah pada hari ke 14, 21, dan 28.

Hasil uji statistik one way Anova pada hari ke-28 memperlihatkan hasil yang berbeda signifikan pada semua kelompok perlakuan. Hal ini menunjukkan adanya efek dari pemberian ekstrak etanol daun nangka dengan dosis yang bervariasi sehingga dilanjutkan dengan uji Lanjut LSD. Hasil uji lanjut menunjukan bahwa kelompok dosis 175 $\mathrm{mg} / \mathrm{kg} \mathrm{BB}$, kelompok dosis $250 \mathrm{mg} / \mathrm{kg} \mathrm{BB}$, dan kelompok dosis $400 \mathrm{mg} / \mathrm{kg}$ BB berbeda signifikan dengan kontrol negatif, dan berbeda tidak signifikan dengan kontrol positif dan kontrol normal. Hal ini menunjukan bahwa pada hari ke-28 kadar glukosa darah tikus Kelompok dosis $175 \mathrm{mg} / \mathrm{kg}$ BB kelompok dosis $250 \mathrm{mg} / \mathrm{kg} \mathrm{BB}$, dan $400 \mathrm{mg} / \mathrm{kg} \mathrm{BB}$ mengalami penurunan kadar glukosa darah mendekati normal dan sebanding dengan kontrol positif.

Berdasarkan hasil preparat histopatologi ginjal tikus dan statistik yang dilakukan, maka dapat diketahui bahwa ekstrak daun nangka dengan dosis $175 \mathrm{mg} / \mathrm{kgBB}$ sudah memiliki pengaruh terhadap regenerasi jaringan ginjal, dengan skoring rat-rata 0,6 
DOI : https://doi.org/10.24843/JFU.2020.v09.i03.p09

pISSN: 2301-7716; eISSN: 2622-4607

Jurnal Farmasi Udayana, Spesial Issue Desember 2020, 204-212

Hal ini menunjukkan sediaan ekstrak adalah sediaan kental yang diperoleh dengan mengekstraksi zat aktif dari simplisia nabati atau simplisia hewani dengan menggunakan pelarut yang sesuai, kemudian menggunakan metode ekstraksi dengan proses penarikan kandungan kimia yang dapat larut dari suatu serbuk simplisia, sehingga terpisah dari bahan yang tidak dapat larut (Depkes RI. 2000).

\section{KESIMPULAN}

Senyawa metabolit sekunder terdapat pada daun nangka (Artocarpus heterophyllus Lamk) yaitu mengandung alkaloid, flavonoid, saponin, polifenol, tanin dan steroid. Ekstrak etanol daun nangka pada dosis $175 \mathrm{mg} / \mathrm{kg} \mathrm{BB}$ dapat memberikan efek terhadap kadar glukosa darah dengan nilai rata-rata $100,8 \pm 36,8 \mathrm{mg} / \mathrm{dL}$ dan pada dosis $175 \mathrm{mg} / \mathrm{kg}$ $\mathrm{BB}$ dengan nilai rata-rata 0,6 dapat regenerasi sel ginjal tikus putih yang diinduksi streptozotocin. Perlu dilakukan penelitian lebih lanjut untuk melihat ada tidaknya potensi toksisitas pada ekstrak daun nangka.

\section{DAFTAR PUSTAKA}

1. Andrie, M., wintari T., dan Rizqa A. 2014. Uji Aktivitas Jamu Gendong Kunyit Asam (Curcuma domestica Val; Tamarindus indica L.) Sebagai Antidiabetes Pada Tikus Yang Diinduksi Streptozotocin. Asian Pacific Journal of Tropical Biomedicine. Vol 7 No3 : 1089-1099. Hal.13-14.

2. Baha Khorioh Miss. 2015. Pengaruh pemberian ekstrak etanol daun nangka (Artocarpus heterophyllus) Terhadap Penurunan Kadar Glukosa Darah Tikus Wistar yang Diinduksi Aloksan. Jurnal Trop Pharmachy Chemistry. Vol 19. No 9. Hal 8

3. David N Shepard, Katherine A. Robinson. 1997. Mechanism of glibenclamide inhibition of cystic fibrosis transmembrane conductance regulator $\mathrm{Cl}$ - channels expressed in a murine cell line. Journal of physiology 503, page 333-346

4. Leila Mousavi, Rabeta Mohd Salleh, Vikneswaran Murugaiyah, Mohd Zaini Asmawi. 2016. Hypoglycemic and antihyperglycemic study of Ocimum tenuiflorum L. leaves extract in normal and streptozotocin-induced diabetic rats. Asian Pacific Journal of Tropical Biomedicine. Vol 6. No 12

5. Nasdiwaty Daud, Rosidah, M Pandapotan Nasution. 2016. Antidiabetic Activity of Ipomoea batatas L. Leaves Extract In Streptozotocin-Induced Diabetic Mice. International Journal of Pharmtech Research. Vol 9. No 3.

6. Omar,S.H., El-Beshbishy, H.A., Moussa, Z., Taha, K.F., and Singab, A.N.B., 2011, Antioxidant Activity of Artocarpus heterophyllus Lam. (Jack Fruit) Leaf Extracts: Remarkable Attenuations of Hyperglycemia and Hyperlipidemia in Streptozotocin- Diabetic Rats, The Scientific World Journal, 788-800.

7. S. V. Tembhurne and D. M. Sakarkar. 2010. Protective effect of Murraya koenigii (L) leaves extract in streptozotocin induced diabetics rats involving possible antioxidant mechanism. Journal of Medicinal Plants Research. Vol 4(22), pp. 2418-2423

8. Tandi J, Suryani As'adm., Rosdiana Natzir., Agussalim Bukhari. 2016. Test Of Ethanol Extract Red Gedi Leaves (Albelmoschus manihot (L.) Medik) In White Rat (Rattus norvegicus) Type 2 Diabetes Melitus. International Journal Of Sciences. Basic and Applied Research (IJSBAR). Volume 3 No, 1. Hal 1-6.

9. Tandi J, H.Z Mutiah, Yuliet dan Yusriadi. 2016. Efektivitas Ekstrak Daun Gedi Merah Terhadap Glukosa Darah, Molandialdehid, 8-hdidroksi-deoksiguanosin, Insulin Tikus Diabetes. Jurnal Trop Pharmachy Cemistry Vol.03 No.04.

10. Tandi J, Roem M, dan Yuliet. 2017. Efek Nefropati Kombinasi Ekstrak Daun Gedi 


\section{Tandi dkk}

DOI : https://doi.org/10.24843/JFU.2020.v09.i03.p09

pISSN: 2301-7716; eISSN: 2622-4607

Jurnal Farmasi Udayana, Spesial Issue Desember 2020, 204-212

Merah dan Kumis Kucing pada Tikus

Induksi Etilen Glikol. Jurnal Trop

Pharmachy Cemistry Vol.04 No.01. Hal

27-34.

11. Tandi J, M Rizky, R Mariani. 2017. Uji

Efek Ekstrak Etanol Daun Sukun

(Artocarpus artilis (Parkinson Ex FA Zorn)

Terhadap Penurunan Kadar Glukosa Darah

Kolesterol. Jurnal Sains dan Kesehatan.

Vol 1. No 8.

12. Tandi J, Ayu Wulandari, Asrifa. 2017. Efek Ekstrak Etanol Daun Gendola Merah (Basella alba L.) terhadap Kadar Kreatinin, Ureum dan Deskripsi Histologis Tubulus Ginjal Tikus Putih Jantan (Rattus norvegicus) Diabetes yang Diinduksi Streptozotocin. Galenika Journal Of Pharmacy. Vol 3. No 2.

13. Trilestari Herni. 2016.Hubungan perilaku diet dengan kadar glukosa sewaktu pada penderita diabetes melitus tipe II di ambar ketawang Yogyakarta. Jurnal Sains dan Kesehatan.hal.1-2 